\title{
A Faunistic Survey on the Hover Flies (Diptera: Syrphidae) of Golestan, Mazandaran and Semnan Provinces, Iran
}

\author{
N. SAMIN ${ }^{1} *$, H. GHAHARI ${ }^{2}$ and J. BENNEWICZ ${ }^{3}$ \\ ${ }^{1}$ Young Researchers and Elite Club, Science and Research Branch, Islamic Azad University, Tehran, Iran \\ ${ }^{2}$ Department of Plant Protection, Yadegar - e-Imam Khomeini (RAH) Shahre Rey Branch, \\ Islamic Azad University, Tehran, Iran \\ ${ }^{3}$ Department of Zoology, Bydgoszcz University of Technology and Life Sciences, Kordeckiego 20, \\ 85-225 Bydgoszcz, Poland
}

(Received: 2 November 2015; accepted: 20 January 2016)

\begin{abstract}
In this paper the fauna of these beneficial insects is studied in some regions of three provinces Golestan, Mazandaran and Semnan (northern Iran). In total 43 species from 23 genera and 2 subfamilies Milesiinae and Syrphinae were collected and identified.
\end{abstract}

Keywords: Diptera, Syrphidae, fauna, Golestan, Mazandaran, Semnan, Iran.

Hover flies (Diptera, Syrphidae) are a large insects group with 200 genera and more than 6000 described species worldwide (Vujic et al., 2008). The family Syrphidae is divided into three subfamilies, viz. Syrphinae, Milesiinae and Microdontinae (Joshi and Ballal, 2013). Majority of aphidophagous syrphids belong to the subfamily Syrphinae. Most species are terrestrial, while a few species are aquatic or live in very moist situation. Among the terrestrial forms at least 25 percent are predacious, chiefly aphidophagous (Mandal and Patnaik, 2006; Suja, 2008). The family has nearly worldwide distribution, and is only absent from Antarctica, remote oceanic islands, and many sub-Antarctic islands, and many sub-Antarctic islands (Bolu and Hayat, 2008). The larvae of hover flies are powerful predators of aphids and can have efficient role in biological control of them (Mandal and Patnaik, 2006; Alhmedi et al., 2010; Bennewicz, 2011).

The fauna of Iranian hover flies, exception a few regions (e.g. northwestern Iran), was poorly studied and upon the checklist of Iranian Syrphidae (Dousti and Hayat, 2006) totally 124 species from 39 genera were listed. After that Kazerani et al. (2013) listed 68 species from 17 genera of the subfamily Syrphinae. Regarding to the syrphids' fauna of Golestan, Mazandaran and Semnan provinces, the fauna of these beneficial insects was not studied well in the mentioned regions, and there are a few publications such as Goldasteh et al. (2002); Ghahari et al. (2008) and Jabbari (2011). Knowledge of biological diversity is a basal step in investigation of ecology, biogeography, evolutionary and con-

*Corresponding author; e-mail: n_samin63@yahoo.com 
servation biology (Vujic et al., 2008). The aim of this paper is the faunistic work on hover flies in Golestan, Mazandaran and Semnan provinces in order to determining the fauna of these beneficial insects in Iran step by step.

\section{Materials and Methods}

The materials were collected by sweeping net and Malaise traps in different regions of Golestan, Mazandaran and Semnan provinces during 2009-2013. The collected materials were placed in a desiccator (having water at its bottom) for soak and soften them. Thereafter, they were pinned and their wings and legs set on appropriate setting boards to facilitate morphological studies and the others were put into tubes filled with $70 \%$ alcohol. The specimens were examined with a stereomicroscope and identified using the relevant literature such as Bezzi (1966); Bei-Bienko (1988); Papp and Darvas (1997, 1998, 2000); Stubbs and Falk (2002); van Veen (2004); Lyneborg and Barkemeyer (2005) and Speight (2011). The materials are preserved in the collections of the authors. The distribution data of Syrphidae mostly suggested by Speight (2011) have been followed.

Golestan province $\left(36.8393^{\circ} \mathrm{N} 54.4444^{\circ} \mathrm{E}\right)$ (Fig. 1) is in the north of Iran and south of the Caspian Sea and covers an area of 20,367 $\mathrm{km}^{2}$. Geographically, Golestan is divided into two sections, the plains and the mountains of the Alborz range. In the eastern Alborz section, the direction of the mountains faces northeast and gradually decreases in height. The highest point of the province is Shavar, at $3945 \mathrm{~m}$ above sea level. Golestan climate is temperate for most of the year.

Mazandaran province $\left(36.5656^{\circ} \mathrm{N} 53.0588^{\circ} \mathrm{E}\right.$ ) (Fig. 2) is located on the southern coast of the Caspian Sea and covers an area of $23,842 \mathrm{~km}^{2}$. Mazandaran province is geo-

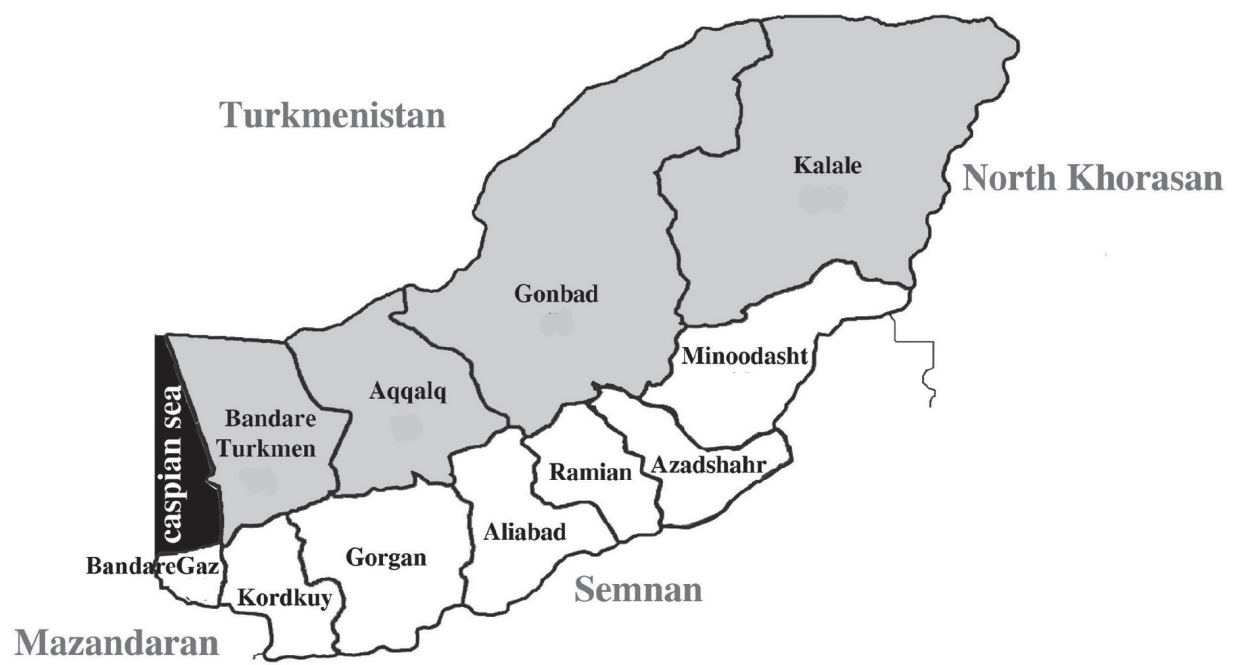

Fig. 1. Golestan province with its cities 


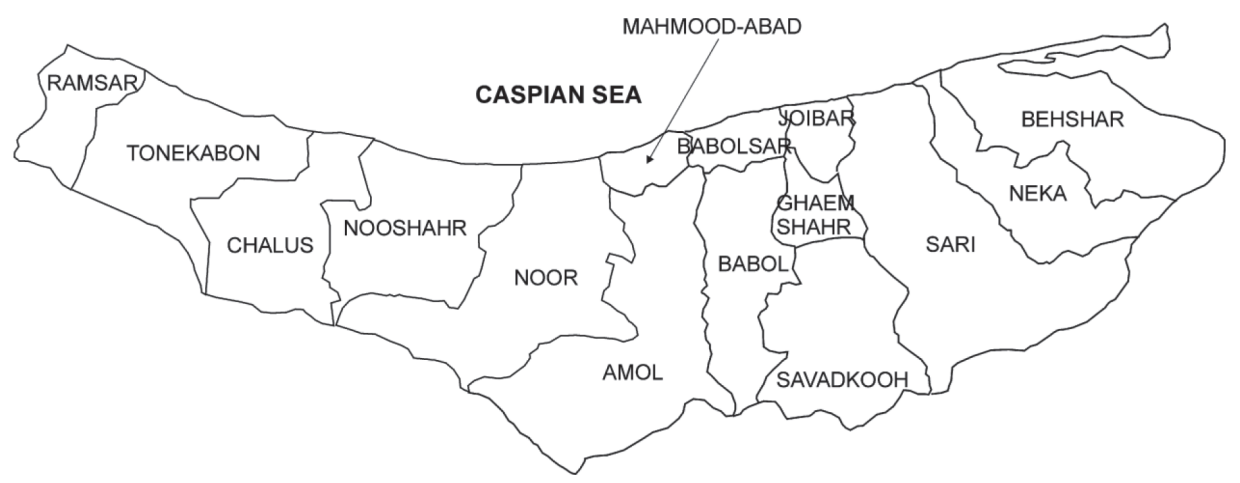

Fig. 2. Mazandaran province with its cities

graphically divided into two parts: the coastal plains, and the mountainous areas. The Alborz Mountain Range surrounds the coastal strip and plains of the Caspian Sea. Given the climatic changes and varying rates of rainfall in different parts of Mazandaran province, this region has a variety of climates, including the mild and humid climate of Caspian shoreline and the moderate and cold climate of mountainous regions.

Semnan province $\left(35.5769^{\circ} \mathrm{N} 53.3953^{\circ} \mathrm{E}\right)$ (Fig. 3) is in the north of the country and covers an area of $97,491 \mathrm{~km}^{2}$ and stretches along the Alborz mountain range and borders to Dasht-e Kavir desert in its southern parts. The province is divided into two parts: a mountainous region, and the plains at the foot of the mountains. The forest of this province lies in the central parts, near its border with Golestan Province. It is one of the oldest forests in Iran which is a remnant of the third geological age.

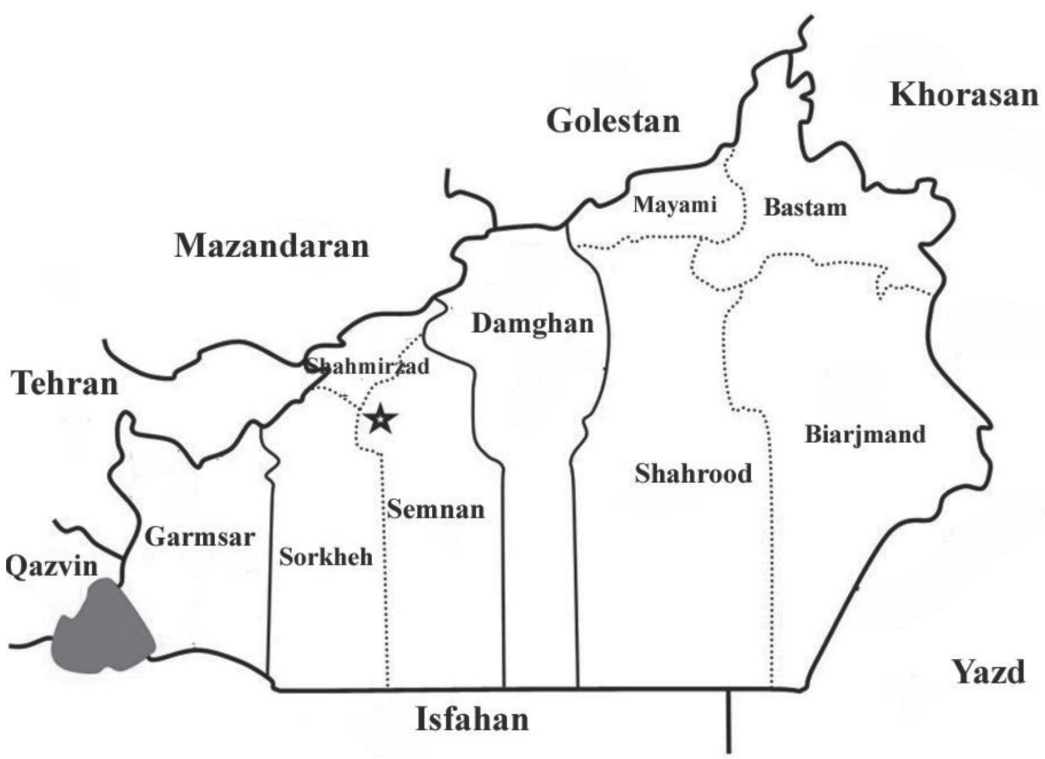

Fig. 3. Semnan province with its cities 


\section{Results}

Totally 43 species from 23 genera, Cheilosia Meigen (2), Chrysogaster Meigen (3), Chrysotoxum Meigen (3), Epistrophe Walker (1), Episyrphus Matsumura et Adachi (1), Eristalinus Rondani (3), Eristalis Latreille (2), Eumerus Meigen (1), Eupeodes Osten Sacken (3), Ischidon Sack (1), Mallota Meigen (1), Melanostoma Schiner (1), Merodon Meigen (3), Myathropa Rondani (1), Orthonevra Macquart (1), Paragus Latreille (3), Scaeva Fabricius (2), Spazigaster Rondani (1), Sphaerophoria Le Peletier et Serville (3), Syritta Le Peletier et Serville (2), Syrphus Fabricius (2), Volucella Geoffroy (2), Xanthogramma Schiner (1) were collected and identified. The list of species is given below with distributional data.

\section{Subfamily Milesiinae Genus Cheilosia Meigen, 1822}

\section{Cheilosia proxima (Zetterstedt, 1843)}

Material examined: Mazandaran province, Savadkooh, $36^{\circ} 05^{\prime} \mathrm{N} 52^{\circ} 55^{\prime} \mathrm{E}, 550 \mathrm{~m}$, 1 , , September 2009.

Distribution outside Iran: Fennoscandia south to Pyrenees and mountainous parts of Spain; Britain eastwards through much of Europe into Turkey and European parts of Russia; in Siberia from the Urals to Kamchatka.

\section{Cheilosia scutellata (Fallen, 1817)}

Material examined: Mazandaran province, Tonekabon, $36^{\circ} 38^{\prime} \mathrm{N} 50^{\circ} 49^{\prime} \mathrm{E}, 55 \mathrm{~m}$, 1 ㅇ, August 2011.

Distribution: Fennoscandia south to Iberia and round the Mediterranean to Greece, Turkey and N Africa; from Ireland eastwards through Eurasia to the Pacific coast.

\section{Genus Chrysogaster Meigen, 1803}

\section{Chrysogaster basalis (Loew, 1857)}

Material examined: Semnan province, Garmsar, $35^{\circ} 00^{\prime} \mathrm{N} 52^{\circ} 20^{\prime} \mathrm{E}, 1$ 오 $10^{\top}$, April 2011.

Distribution outside Iran: from northern France and southern Germany south to Spain and Portugal and in N Africa, Switzerland, Romania and much of the Balkan Peninsula (Bosnia-Herzegovina, Croatia, Greece, Macedonia, Serbia), Ukraine, Kazakhstan and Tajikistan.

\section{Chrysogaster viduata (Linnaeus, 1758)}

Material examined: Mazandaran province, Savadkooh, $36^{\circ} 05^{`} \mathrm{~N} 52^{\circ} 55^{\prime} \mathrm{E}, 550 \mathrm{~m}$, $10^{\top}$, September 2009.

Distribution outside Iran: Norway, Sweden, Finland, Denmark, The Netherlands, Belgium, Luxembourg, Germany, Poland, Czech Republic and Slovakia, France, Austria, 
Hungary, Spain, Italy, the former Yugoslavia, Bulgaria, USSR-Central and South European territories, Transcaucasus.

\section{Chrysogaster virescens (Loew, 1854)}

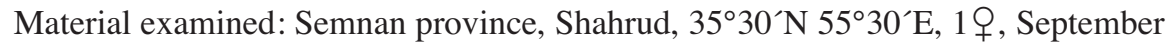
2011.

Distribution outside Iran: Southern Finland, Ireland, Britain and the Atlantic seaboard of Europe from Denmark to the Pyrenees and northern Spain, Switzerland and central Europe.

\section{Genus Eristalinus Rondani, 1845}

\section{Eristalinus aeneus (Scopoli, 1763)}

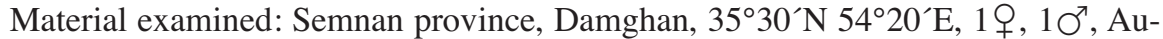

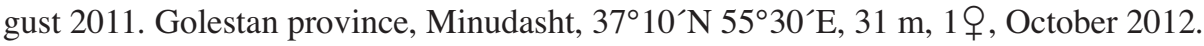

Distribution outside Iran: Cosmopolitan; southern Sweden south to N Africa and the Canary Isles; on into the Afrotropical region south to Kenya and Tanzania; from Ireland eastwards through central and southern Europe and on through Russia and China to the Pacific and south into the Oriental region; Mauritius; in North America from Minnesota and Ontario south to California and Texas; Hawaii, Australia and the Gilbert and Ellis islands in Australasia; Bermuda.

\section{Eristalinus sepulchralis (Linnaeus, 1785)}

Material examined: Mazandaran province, Amol, $36^{\circ} 28^{\prime} \mathrm{N} 52^{\circ} 21^{\prime} \mathrm{E}, 198 \mathrm{~m}, 1^{\text {O }}$, June 2012.

Distribution outside Iran: Fennoscandia south to Iberia and the Mediterranean, including North Africa; from Ireland through most of Europe into Turkey and European parts of Russia; through Siberia to the Pacific coast; Japan; China; India.

\section{Eristalinus taeniops (Wiedemann, 1818)}

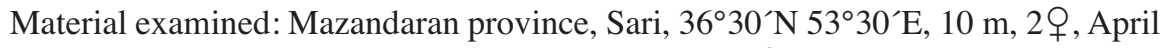

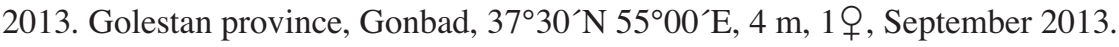

Distribution outside Iran: Portugal, Spain and round the Mediterranean basin southern France including Corsica, Italy including Sardinia and Sicily, parts of the former Yugoslavia, Albania, Roumania, Cyprus, Greece (including Crete and Rhodes), Turkey, Lebanon, Israel, North Africa (Syria, Egypt, Libya, Tunisia, Morocco), Canary Islands, Transcaucasus; in eastern parts of the Afrotropical region down to South Africa (inclusive) and in Nepal and parts of Pakistan and northern India in the Oriental region. 


\section{Genus Eristalis Latreille, 1804}

\section{Eristalis arbustorum (Linnaeus, 1758)}

Material examined: Mazandaran province, Savadkooh, $36^{\circ} 05^{\prime} \mathrm{N} 52^{\circ} 55^{\prime} \mathrm{E}, 550 \mathrm{~m}$, 2 , , September 2009.

Distribution outside Iran: Throughout the Palaearctic region, including North Africa; North America from Wisconsin to Labrador and south to Kansas and South Carolina; reaches the Oriental region in northern India.

\section{Eristalis tenax (Linnaeus, 1758)}

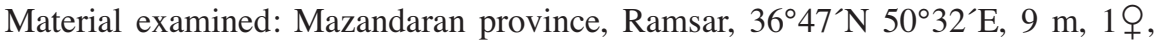

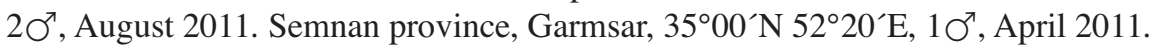

Distribution outside Iran: highly migratory; cosmopolitan; the most widely distributed syrphid species in the world, known from all regions except the Antarctic; found throughout Europe except in the far north. It occasionally reaches offshore islands of northern Europe, such as the Faroes.

\section{Genus Eumerus Meigen, 1822}

\section{Eumerus basalis Loew, 1848}

Material examined: Mazandaran province, Ramsar, $36^{\circ} 47^{\prime} \mathrm{N} 50^{\circ} 32^{`} \mathrm{E}, 9 \mathrm{~m}, 1$, August 2011.

Distribution outside Iran: Mediterranean parts of Europe, from southern France (plus Corsica) to Greece (including Crete and Rhodes), Croatia, Montenegro and Serbia, plus Bulgaria, Romania and the Ukraine; Turkey.

\section{Genus Mallota Meigen, 1822}

\section{Mallota auricoma Sack, 1910}

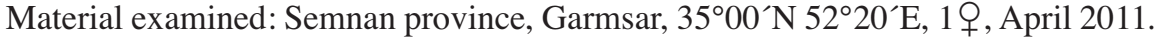

Distribution outside Iran: Central European territory, Soviet Middle Asia. Uzbekistan, Tajikistan, Kyrgyzstan, Turkmenistan; West and East Siberia, Far East, China, Mongolia.

\section{Genus Merodon Meigen, 1803}

\section{Merodon aberrans Egger, 1860}

Material examined: Mazandaran province, Noor, $36^{\circ} 19^{\prime} \mathrm{N} 52^{\circ} 00^{\prime} \mathrm{E}, 8 \mathrm{~m}, 1 \mathrm{O}^{\prime}$, June 2012.

Distribution outside Iran: Through central Europe from Germany, the Czech Republic and the Alps (France, Switzerland, Austria) to Hungary and Romania and on to the Ukraine and southern Russia; in southern Europe from mountainous parts of Portugal and Spain eastwards to Italy, Albania, the former Yugoslavia and Greece and on to Turkey and 
round the Mediterranean (Lebanon) into N Africa (Morocco), including Mediterranean islands, e.g. Crete.

\section{Merodon armipes Rondani, 1843}

Material examined: Mazandaran province, Savadkooh, $36^{\circ} 05^{\prime} \mathrm{N} 52^{\circ} 55^{\prime} \mathrm{E}, 550 \mathrm{~m}$, $10^{\prime}$, September 2009. Golestan province, Minudasht, $37^{\circ} 10^{\prime} \mathrm{N} 55^{\circ} 30^{\prime} \mathrm{E}, 31 \mathrm{~m}, 1^{\text {Q }}$, October 2012.

Distribution outside Iran: From north-east France (Rhine valley in Alsace) and adjacent parts of Germany. Through central Europe (Switzerland) and mountainous parts of northern Italy into the former Yugoslavia and on to Bulgaria, Romania and the Crimea; Greece, Israel, North Africa.

\section{Merodon nanus (Sack, 1931)}

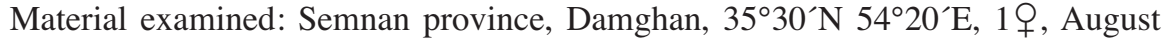
2011.

Distribution outside Iran: The former Yugoslavia, Bulgaria, Transcaucasus (Georgia and Armenia), Iraq and Turkey.

\section{Genus Myathropa Rondani, 1845}

\section{Myathropa florea (Linnaeus, 1758)}

Material examined: Mazandaran province, Amol, 36 ${ }^{\circ} 28^{\prime} \mathrm{N} 52^{\circ} 21^{\prime} \mathrm{E}, 198 \mathrm{~m}, 1$, June 2012.

Distribution outside Iran: From Fennoscandia south to Iberia and the Mediterranean, the Canary Isles and North Africa; from Ireland eastwards through Eurasia to the Pacific coast.

\section{Genus Orthonevra Macquart, 1829}

\section{Orthonevra nobilis (Fallen, 1817)}

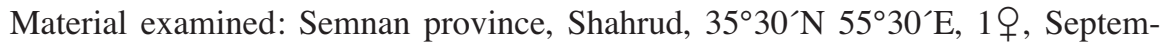
ber 2011.

Distribution outside Iran: China, European parts of Russia, Greece, Ireland, Italy, Norway, Siberia, Spain, Turkey, former Yugoslavia.

\section{Genus Spazigaster Rondani, 1843}

\section{Spazigaster ambulans (Fabricius, 1798)}

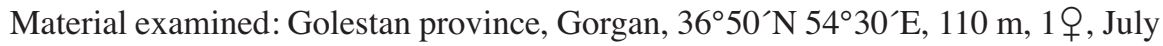
2011. Mazandaran province, Ramsar, 3647’N 50³2`E, 9 m, $10^{\top}$, August 2011.

Distribution outside Iran: Germany, Alps, Apennines, Hungary, northern parts of the former Yugoslavia, the Carpathians, the Caucasus, Turkey. 


\section{Genus Syritta Le Peletier et Serville, 1828}

\section{Syritta flaviventris Macquart, 1842}

Material examined: Mazandaran province, Sari, 36³ $30^{\prime} \mathrm{N} 53^{\circ} 30^{\prime} \mathrm{E}, 10 \mathrm{~m}, 2$,, $1 \mathrm{O}^{\prime}$, April 2013.

Distribution outside Iran: Portugal, Spain and round the Mediterranean from the southern coast of France to Turkey and on to north Africa; in eastern parts of the Afrotropical region to the southern tip of Africa and in Madagascar. Known from various Mediterranean islands: Corsica, Sardinia, Sicily, Crete, plus Cape Verde. Also, cited from Argentina, Brazil and Chile in the Neotropical region and Easter Island in Oceania (to which it has supposedly been introduced).

\section{Syritta pipiens (Linnaeus, 1758)}

Material examined: Semnan province, Damghan, $35^{\circ} 30^{\prime} \mathrm{N} 54^{\circ} 20^{\prime} \mathrm{E}, 1$ 우, $1 \mathrm{O}^{\prime}$, August 2011.

Distribution outside Iran: Becoming cosmopolitan; known from most of the Palaearctic, including North Africa, most of North America, South America and the Oriental region. But records from the Afrotropical region are apparently erroneous.

\section{Genus Volucella Geoffroy, 1762}

\section{Volucella inanis (Linnaeus, 1758)}

Material examined: Mazandaran province, Tonekabon, $36^{\circ} 38^{\prime} \mathrm{N} 50^{\circ} 49^{\prime} \mathrm{E}, 55 \mathrm{~m}$, $10^{\top}$, August 2011.

Distribution outside Iran: From southern Fennoscandia south to Spain and the Mediterranean (including islands, e.g. Crete), north Africa and Asia Minor (Syria); from Britain (southern England) eastwards through central and southern Europe into Turkey and European parts of Russia and on through Siberia to the Pacific; Afghanistan, Mongolia, China.

\section{Volucella zonaria (Poda, 1761)}

Material examined: Mazandaran province, Amol, 36² $28^{\prime} \mathrm{N} 52^{\circ} 21^{\prime} \mathrm{E}, 198 \mathrm{~m}, 2$, June 2012.

Distribution outside Iran: From Poland south to the Mediterranean (including islands, e.g. Crete) and North Africa; from Britain (southern England) eastwards through central and southern Europe (Italy, the former Yugoslavia, Greece) into Turkey and European parts of Russia and on through Siberia to the Pacific; Mongolia.

\section{Subfamily Syrphinae \\ Genus Chrysotoxum Meigen, 1803}

\section{Chrysotoxum elegans Loew, 1841}

Material examined: Golestan province, Kalaleh, $37^{\circ} 43^{\prime} \mathrm{N} 55^{\circ} 49^{\prime} \mathrm{E}, 150 \mathrm{~m}, 1 \mathrm{O}^{\top}$, July 2011 . 
Distribution outside Iran: Fennoscandia south to Iberia and the Mediterranean; through central and southern Europe into European parts of Russia as far as the Caucasus Mountains and into Turkey.

\section{Chrysotoxum festivum (Linnaeus, 1758)}

Material examined: Mazandaran province, Noor, $36^{\circ} 19^{\prime} \mathrm{N} 52^{\circ} 00^{\prime} \mathrm{E}, 8 \mathrm{~m}, 1$, , June 2012.

Distribution outside Iran: Asia: Ireland, Japan, Mongolia, Norway, Sweden, Finland, Spain, Italy, former Yugoslavia, Bulgaria, USSR from Kola to Transcaucasus, Kazakhstan, Siberia, Far East, United Kingdom.

\section{Chrysotoxum vernale Loew, 1841}

Material examined: Mazandaran province, Behshahr, $36^{\circ} 41^{\prime} \mathrm{N} 53^{\circ} 44^{\prime} \mathrm{E}, 57 \mathrm{~m}, 1$, April 2013.

Distribution outside Iran: Fennoscandia south to the Pyrenees; from Britain (southern England) eastwards through most of Europe into Asia almost to the Pacific.

\section{Genus Epistrophe Walker, 1852}

\section{Epistrophe euchroma (Kowarz, 1885)}

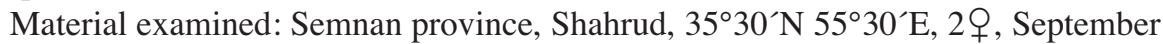
2011.

Distribution outside Iran: Northern Fennoscandia south to the Pyrenees and central Spain; from Britain (southern England) eastwards through central Europe into Russia, reaching the Caucasus in the south and eastern Siberia (Yakut) in Asia.

\section{Genus Episyrphus Matsumura et Adachi, 1917}

\section{Episyrphus balteatus (De Geer, 1776)}

Material examined: Mazandaran province, Savadkooh, $36^{\circ} 05^{\prime} \mathrm{N} 52^{\circ} 55^{\prime} \mathrm{E}, 550 \mathrm{~m}$, $10^{\prime}$, September 2009. Mazandaran province, Qaemshahr, $36^{\circ} 28^{\prime} \mathrm{N} 52^{\circ} 52^{\prime} \mathrm{E}, 8 \mathrm{~m}, 1$, , July 2010. Semnan province, Semnan, $35^{\circ} 20^{\prime} N 53^{\circ} 20^{\prime} \mathrm{E}, 10^{\top}$, June 2011. Semnan province, Shahmirzad, $35^{\circ} 42^{\prime} \mathrm{N} 53^{\circ} 21^{\prime} \mathrm{E}, 1^{\circ}$, June 2011. Mazandaran province, Babol, $36^{\circ} 30^{\prime} \mathrm{N}$ $52^{\circ} 35^{\prime} \mathrm{E}, 25 \mathrm{~m}, 1$ ㅇ, $10^{\prime}$, June 2012. Mazandaran province, Noor, $36^{\circ} 19^{\prime} \mathrm{N} 52^{\circ} 00^{\prime} \mathrm{E}, 8 \mathrm{~m}$,

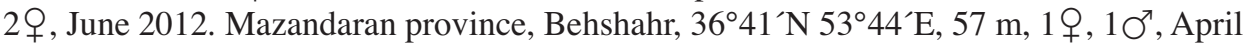

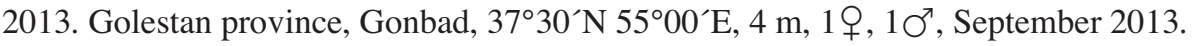

Distribution outside Iran: Fennoscandia to the Mediterranean; Canary Isles, Azores and N Africa; Ireland through Eurasia to the Pacific coast; south through the Oriental region to Sri Lanka; Australia. 


\section{Genus Eupeodes Osten Sacken, 1877}

\section{Eupeodes corollae (Fabricius, 1794)}

Material examined: Mazandaran province, Savadkooh, $36^{\circ} 05^{\prime} \mathrm{N} 52^{\circ} 55^{\prime} \mathrm{E}, 550 \mathrm{~m}$, 1 으. September 2009. Mazandaran province, Qaemshahr, $36^{\circ} 28^{\prime} \mathrm{N} 52^{\circ} 52^{\prime} \mathrm{E}, 8 \mathrm{~m}, 1^{\circ}$,

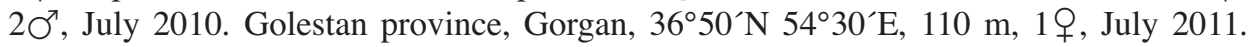
Semnan province, Shahmirzad, $35^{\circ} 42^{\prime} \mathrm{N} 53^{\circ} 21^{\prime} \mathrm{E}$, 1 , , June 2011. Golestan province,

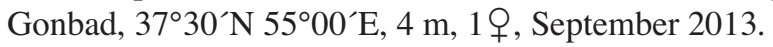

Distribution outside Iran: from Iceland, Fennoscandia and the Faroes, south to Iberia, the Mediterranean, Madeira, the Canary Isles and N Africa; coastal States of Africa down to and including S Africa; Mauritius; from Ireland eastwards through most of Europe into European parts of Russia; through Siberia from the Urals to the Pacific coast; Japan; China; Formosa.

\section{Eupeodes latifasciatus (Macquart, 1829)}

Material examined: Semnan province, Semnan, 35²0`N 5320`E, 1오, June 2011.

Distribution outside Iran: From Iceland and Fennoscandia south to Iberia, the Mediterranean (including Cyprus), N Africa and Turkey; from Ireland eastwards through most of Europe into European parts of Russia; through Siberia from the Urals to the Pacific coast (Sakhalin and Kuril Isles); India; in N America from Alaska south to California and Texas.

\section{Eupeodes nuba (Wiedemann, 1830)}

Material examined: Mazandaran province, Babol, $36^{\circ} 30^{\prime} \mathrm{N} 52^{\circ} 35^{`} \mathrm{E}, 25 \mathrm{~m}, 1$, $10^{7}$, June 2012.

Distribution outside Iran: Canary Isles, Mediterranean basin, from southern France to Italy (Sicily) and parts of the former Yugoslavia, Crete, Cyprus, Lebanon, Israel, Egypt and Morocco; Switzerland in central Europe, Romania; Transcaucasus and south-western parts of Asia (Uzbekistan, Kyrgyzstan, Tajikistan) to Afghanistan and Mongolia. In eastern parts of the Afrotropical region from Ethiopia south to South Africa (inclusive).

\section{Genus Ischidon Sack, 1913}

\section{Ischidon aegyptius (Wiedemann, 1830)}

Material examined: Mazandaran province, Behshahr, $36^{\circ} 41^{\prime} \mathrm{N} 53^{\circ} 44^{\prime} \mathrm{E}, 57 \mathrm{~m}, 1 \mathrm{O}^{\prime}$, April 2013.

Distribution outside Iran: Throughout the Afrotropical region and into N Africa to the coast of the Mediterranean and Yemen; southern Spain, southern Italy, the Balearic Islands and the Canaries. 


\section{Genus Melanostoma Schiner, 1860}

\section{Melanostoma scalare (Fabricius, 1794)}

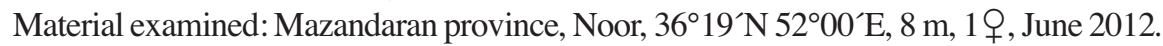

Distribution outside Iran: From Iceland and Fennoscandia south to Iberia, the Mediterranean and North Africa; from Ireland eastwards through most of Europe into European parts of Russia; in Siberia from the Urals to the Pacific coast (Kuril Isles); in eastern parts of the Afrotropical region south to Zimbabwe; throughout the Oriental region to New Guinea.

\section{Genus Paragus Latreille, 1804}

\section{Paragus (Paragus) antoinettae Goeldlin and Lucas, 1981}

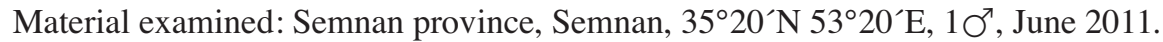

Distribution outside Iran: Asiatic Russia, France, Israel, Kyrgyzstan, Romania, Tajikistan, Turkmenistan, former Yugoslavia.

\section{Paragus compeditus Wiedemann, 1830}

Material examined: Mazandaran province, Babol, $36^{\circ} 30^{\prime} \mathrm{N} 52^{\circ} 35^{\prime} \mathrm{E}, 25 \mathrm{~m}, 1$, June 2012.

Distribution outside Iran: USSR-South European territory, Transcaucasus, Kazakhstan, Soviet Middle Asia, Afghanistan, North China, Egypt, Turkey.

\section{Paragus (Paragus) quadrifasciatus Meigen, 1822}

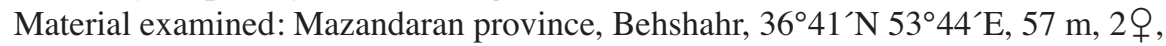
April 2013.

Distribution outside Iran: China, European parts of Russia, France, Greece, Japan, Kazakhstan, Kyrgyzstan, Korea, North Africa, Portugal, Romania, south to the Mediterranean, Tajikistan, Turkey, Turkmenistan.

\section{Genus Scaeva Fabricius, 1850}

\section{Scaeva albomaculata (Macquart, 1842)}

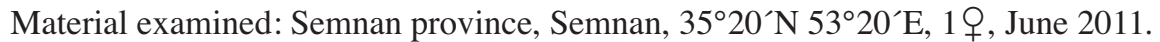

Distribution outside Iran: Iberian peninsula and round the Mediterranean basin to Morocco; Canary Islands; eastward through southern Russia, the Caucasus and southern Siberia to the far east and northern China; Afghanistan, Mongolia; highly migratory and occasionally reaches as far north as Britain.

\section{Scaeva pyrastri (Linnaeus, 1758)}

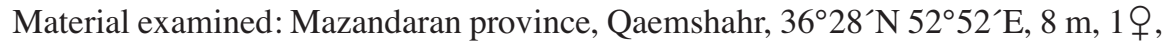

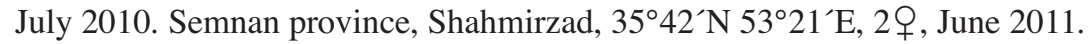

Distribution outside Iran: Fennoscandia south to Iberia, the Mediterranean, Canary Isles and North Africa; from Ireland east through much of Europe and Asia Minor into 
European Russia; through Siberia from the Urals to the Pacific coast (Kuril Isles); India; China; North America from Alaska to California and New Mexico.

\section{Genus Sphaerophoria Le Peletier et Serville, 1828}

\section{Sphaerophoria rueppelli (Wiedemann, 1830)}

Material examined: Mazandaran province, Tonekabon, $36^{\circ} 38^{\prime} \mathrm{N} 50^{\circ} 49^{\prime} \mathrm{E}, 55 \mathrm{~m}$, $10^{\top}$, August 2011.

Distribution outside Iran: from southern Norway and Sweden south to N Africa and the Canary Isles; from Ireland east through central and southern Europe, including Greece, Turkey and Mediterranean islands into Asia Minor, Russia and Afghanistan and on to the Pacific coast, China and Korea; in eastern parts of the Afrotropical region south to Kenya.

\section{Sphaerophoria scripta (Linnaeus, 1758)}

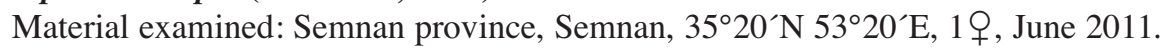

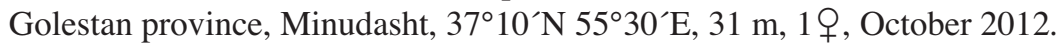

Distribution outside Iran: A highly migratory species; southwest Greenland, Iceland and Fennoscandia south to the Mediterranean, the Canary Isles and N Africa; from Ireland eastwards through much of the Palaearctic to the Pacific coast of Asia; Kashmir and Nepal.

\section{Sphaerophoria turkmenica Bankowska, 1964}

Material examined: Semnan province, Shahmirzad, $35^{\circ} 42^{\prime} \mathrm{N} 53^{\circ} 21^{\prime} \mathrm{E}, 1$, , June 2011.

Distribution outside Iran: Romania, USSR-South European territory, Transcaucasus, Soviet Middle Asia, Afghanistan, Turkey.

\section{Genus Syrphus Fabricius, 1775}

\section{Syrphus ribesii (Linnaeus, 1758)}

Material examined: Mazandaran province, Savadkooh, $36^{\circ} 05^{\prime} \mathrm{N} 52^{\circ} 55^{\prime} \mathrm{E}, 550 \mathrm{~m}$,

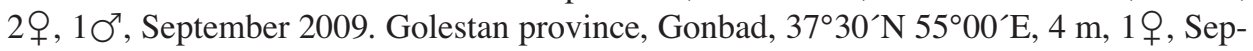
tember 2013.

Distribution outside Iran: From Iceland and Fennoscandia south to Iberia and the Mediterranean; Canary Isles; from Ireland eastwards through most of Europe into Turkey, European parts of Russia and Afghanistan; from the Urals to the Pacific coast (Kuril Isles); Japan; North America from Alaska south to central parts of the USA.

\section{Syrphus vitripennis Meigen, 1822}

Material examined: Mazandaran province, Savadkooh, $36^{\circ} 05^{\prime} \mathrm{N} 52^{\circ} 55^{\prime} \mathrm{E}, 550 \mathrm{~m}$,

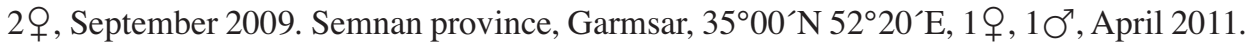

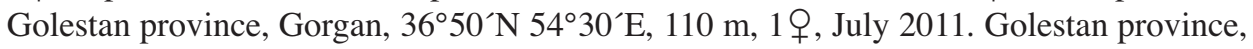


Kalaleh, $37^{\circ} 43^{\prime} \mathrm{N} 55^{\circ} 49^{\prime} \mathrm{E}, 150 \mathrm{~m}, 10^{\top}$, July 2011 . Mazandaran province, Sari, $36^{\circ} 30^{\prime} \mathrm{N}$ $53^{\circ} 30^{\prime} \mathrm{E}, 10 \mathrm{~m}, 1$ ㅇ, $10^{\top}$, April 2013.

Distribution outside Iran: Throughout most of the Palaearctic region, including N Africa; in North America from Alaska to California; Formosa.

\section{Genus Xanthogramma Schiner, 1860}

\section{Xanthogramma pedissequum (Harris, 1776)}

Material examined: Semnan province, Shahmirzad, $35^{\circ} 42^{\prime} \mathrm{N} 53^{\circ} 21^{\prime} \mathrm{E}, 1$, , June 2011.

Distribution outside Iran: Uncertain, due to confusion with related species, but from Britain and Atlantic seaboard countries south to the Paris basin and into central Europe to the Alps (France, Switzerland).

\section{Discussion}

Totally 90 specimens of Syrphidae (43 species from 23 genera) were collected in this investigation which indicates that the fauna of hover flies is diverse in Golestan, Mazandaran and Semnan provinces. In this research the number of sampled regions in Mazandaran province was more than the two other provinces; so the specimens were collected from 34 localities of Mazandaran, 21 localities of Semnan and 12 localities of Golestan. Among the recorded species in this research, Episyrphus balteatus is the dominant species in all the midfield thickets. This species can have four or more generations annually. It is found in the colonies of a number of aphid species throughout the growing season. The co-dominant species Eupeodes corollae (formerly Metasyrphus corollae) and Syrphus vitripennis also have more than one generation per year. This faunistic survey covered some areas of the mentioned three provinces while these regions are large with various geographical regions and climates. Therefore we expect more than species which will be recorded if the samplings are continued.

\section{Acknowledgements}

The authors are grateful to R. Hayat (Turkey), A. Jabbari and H. Sakenin (Iran) for their valuable helps in progress of this research. The research was supported by Islamic Azad University (Young Researchers and Elite Club, Yadegar-e-Imam Khomeini (RAH) Shahre Rey Branch) and Bydgoszcz University of Technology and Life Sciences. 


\section{Literature}

Alhmedi, A., Haubruge, E. and Francis, F. (2010): Intraguild interactions and aphid predators: biological efficiency of Harmonia axyridis and Episyrphus balteatus. J. Appl. Entomol. 134, 34-44.

Bei-Bienko, G. (1988): Keys to the Insects of the European Part of the USSR. Vol. V. Diptera and Siphonaptera. Part II. Smithonian Institution Libraries and the National Science Foundation Washington, D.C., pp. $10-148$.

Bennewicz, J. (2011): Aphidivorous hoverflies (Diptera: Syrphidae) at field boundaries and woodland edges in an agricultural landscape. Polish J. Entomol. 80, 129-149.

Bezzi, M. (1966): The Syrphidae of the Ethiopian Region. Johnson Reprint Corporation. Printed in the U.S.A., $146 \mathrm{p}$.

Bolu, H. and Hayat, R. (2008): A New host [Parthenolecanium persicae (Homoptera: Coccidae)] record for Eupeodes corollae (Fabricius) (Diptera: Syrphidae) from Turkey. Turkish J. Zoology 32, 79-84.

Dousti, A. F. and Hayat, R. (2006): A catalogue of the Syrphidae (Insecta: Diptera) of Iran. J. Entomol. Research. Society 8, 5-38.

Ghahari, H., Hayat, R., Tabari, M. and Ostovan, H. (2008): Hover flies (Diptera: Syrphidae) from rice fields and around grasslands of Northern Iran. Munis Entomol. and Zoology 3, 275-284.

Goldasteh, Sh., Bayat Asadi, H., Shojaee, M. and Baniameri, V. A. (2002): A faunistic survey of Syrphidae (Diptera) in Gorgan region. Proc. of the $15^{\text {th }}$ Iranian Plant Protection Congress, $168 \mathrm{p}$.

Jabbari, A. (2011): Species diversity of hover flies (Diptera: Syrphidae) and determination of dominant species in Garmsar region. M. Sc thesis of Entomology, Islamic Azad University, Science and Research Branch.

Joshi, S. and Ballal, C. R. (2013): Syrphid predators for biological control of aphids. J. Biol. Control 27, 151-170.

Kazerani, F., Talebi, A. A. and Gilasian, E. (2013): An annotated checklist of the subfamily Syrphinae (Diptera: Syrphidae) of Iran. Entomofauna 34, 517-556.

Lyneborg, L. and Barkemeyer, W. (2005): The Genus Syritta: A World Revision of the Genus Syritta. Vol. 15. Apollo Books Publication, Stenstrup, 224 p.

Mandal, S. M. A. and Patnaik, N. C. (2006): Predatory potential of aphidophagous predators associated with cabbage crop. J. Plant Protection Environment 3, 81-86.

Papp, L. and Darvas, B. (1997, 1998, 2000): Contributions to a Manual of Palearctic Diptera. Vol. I: (2000) 978 p., Vol. II: (1998) 592 p., Vol. III: (1997) 880 p. Science Heraid, Budapest.

Speight, M. C. D. (2011): Species accounts of European Syrphidae (Diptera). In: M. C. D. Speight, E. Castella, J.-P. Sarthou and C. Monteil, (eds): Syrph the Net, the Database of European Syrphidae. Syrph the Net Publication, Dublin, Vol. 65, 285 p.

Stubbs, A. E. and Falk, S. J. (2002): British Hover Flies. An Illustrated Identification Guide. Pub. The British Entomology and Natural History Society, Reading, UK, 467 p.

Suja, G. (2008): Biology and feeding potential of the syrphid predator Ischiodon scutellaris (Fab.) on Aphis craccivora Koch. in cowpea. Current Biotica 2, 230-233.

van Veen, M. (2004): Hoverflies of Northwest Europe: Identification Keys to the Syrphidae. KNNV Publishing, Utrecht, $256 \mathrm{p}$.

Vujic, A., Radenkovic, S. and Polic, D. (2008): A review of the luteitarsis group of the genus Pipiza Fallén (Diptera: Syrphidae) with description of a new species from the Balkan Peninsula. Zootaxa 1845, 33-46. 